\title{
Antibiotic and Bacteriocin Sensitivity of Listeria monocytogenes Strains Isolated from Different Foods
}

\author{
Evrim Gunes Altuntas ${ }^{1}$, Deniz Kocan ${ }^{2}$, Serap Cosansu ${ }^{3 *}$, Kamuran Ayhan ${ }^{1}$, Vijay K. Juneja ${ }^{4}$, \\ Luis Materon ${ }^{5}$
}

${ }^{1}$ Food Engineering Department, Engineering Faculty, Ankara University, Ankara, Turkey; ${ }^{2}$ Food Technology Department, Guzelyurt Vocational School, Aksaray University, Guzelyurt, Turkey; ${ }^{3}$ Food Engineering Department, Engineering Faculty, Sakarya University, Sakarya, Turkey; ${ }^{4}$ Agricultural Research Service, United States Department of Agriculture (USDA), Eastern Regional Research Center, Microbial Food Safety Research Unit, Wyndmoor, USA; ${ }^{5}$ Biology Department, University of Texas Pan American, Edinburg, USA. Email: "scosansu@sakarya.edu.tr

Received November $29^{\text {th }}, 2011$; revised February $1^{\text {st }}, 2012$; accepted February $8^{\text {th }}, 2012$

\begin{abstract}
This study aimed to determine the antibiotic and bacteriocin sensitivity of $\langle i>$ Listeria monocytogenes $</ i>$ strains isolated from animal derived foods. With disc diffusion assay, all fourteen L. monocytogenes strains were susceptible to the antibiotics, including penicillin $\mathrm{G}$, vancomycin, tetracycline, chloramphenicol, rifampicin, erythromycin, gentamicin and trime- thoprim. However, the percentages of fosfomycin and streptomycin resistances were $92.9 \%$ and $7.1 \%$, respectively. Multiple resistances were not observed among the tested strains. The results of well diffusion assays showed that all strains were inhibited by the cell-free supernatant of a bacteriocin-producing strain, Pediococcus acidilactici 13, with the inhibition zones ranging from 16.00 to $24.50 \mathrm{~mm}$. These results provide useful information on antibiotic resistance of $L$. monocytogenes strains isolated from foods, and can potentially be used to develop bacteriocin-based interventions to guard against the hazards associated with $L$. monocytogenes in ready-to-eat meat and poultry products.
\end{abstract}

Keywords: Listeria; Antibiotic; Bacteriocin

\section{Introduction}

Listeria monocytogenes is one of the most important food-borne pathogens due to its widespread distribution in nature $[1,2]$. Consumption of food contaminated with this pathogen can lead to listeriosis with high rates of morbidity and mortality (25\% - 30\% overall) [3-5]. Raw meat, dairy foods, non pasteurized milk and soft or semisoft cheeses, vegetables and fish are major sources of outbreaks of listeriosis [6,7]. Also, ready-to-eat (RTE) foods [8-10] may act as vehicles of transmission of this pathogen. Therefore, all available technological and hygienic prophylactic measures must be adopted to eliminate any chance of contamination of foods with this pathogen.

Currently, non-thermal preservation methods are of growing interest as alternative treatments, especially high intensity pulsed electric fields (HIPEF), high pressure (HP) [11] and the addition of natural antimicrobial substances such as lactic acid and other end products of LAB metabolism, including hydrogen peroxide, diacetyl, acetoin and other organic acids [12]. One promising method among

"Corresponding author. these prevention methods to control L. monocytogenes, is using bacteriocins as antimicrobial agent. Bacteriocin and similar metabolites produced by certain lactic acid bacteria, isolated from different types of foods, have been known to inhibit the growth of Listeria monocytogenes [13-15] and these antimicrobial peptides can be considered as alternatives to the use of chemical preservatives [16].

Although human listeriosis is very rare, when it occurs it can be fatal or causes serious health problems especially in the susceptible population groups, including the elderly people, pregnant women, fetuses, neonates and immunocompromised individuals [10]. Ampicillin or ampicillin in combination with an aminoglycoside such as streptomycin or gentamicin is the primary choice for therapy [17]. The antibiotic resistance of the pathogen is a significant public health concern [18]. The first antibiotic resistant L. monocytogenes strain was reported in 1988. Since then, an increasing number of resistant strains isolated from foods, animals and humans have been reported [19-21]. The studies in the last decade have provided sufficient evidence to document that Listeria spp. including L. monocytogenes are resistant to various anti- 
biotics such as rifampin, cephalothin, nalidixic acid, penicillin G, sulphamethoxole/trimethoprim, chloramphenicol, tetracycline, oxacillin, lincomycin, flumequine, clindamycin, cefotaxime, cephalosporine, ampicillin, erythromycin, gentamycin, methicillin, teicoplanin, tetracycline and vancomycin [4,5,7,21-25]. Such studies are of significant public health significance since it is of concern that there is a worldwide increase in antibiotic resistance of L. monocytogenes. It is suggested that the increased use of antibiotics for therapeutic purposes in animals and humans may lead to the development of antibiotic resistance [22, $26,27]$. Since another factor effective on the level of resistance is the geographical differences, it is found necessary to screen the antibiotic resistance patterns of $L$. monocytogenes in food and environmental sources from different geographic areas [27].

In one of our previous studies [13], the bacteriocin producer strain was identified as Pediococcus acidilactici by API $50 \mathrm{CHL}$ and $16 \mathrm{~S}$ rRNA gene sequencing. The bacteriocin activity of the inhibitor substance produced by this strain was $9244 \mathrm{AU} / \mathrm{ml}$. Optimization studies on growth conditions and growth media increased the bacteriocin activity to $204,800 \mathrm{AU} / \mathrm{ml}$. In a study [15], when Pediococcus strain was used as a starter culture in sucuk production, the metabolite(s) of the Pediococcus strain exhibited antilisterial activity, reduced levels of L. monocytogenes and controlled its growth when inoculated post-processing. Therefore, the aim of this study was to evaluate the susceptibility of fourteen $L$. monocytogenes strains isolated from animal-derived food products to a variety of antibiotics and bacteriocin produced by Pediococcus acidilactici 13 .

\section{Materials and Methods}

\subsection{Materials}

Fourteen Listeria monocytogenes strains isolated from raw or cooked foods including sausage, raw minced beef, chicken breast, chicken gizzard, raw meat, raw milk, cooked turkey döner, anchovy and mussel were used in antibiotic and bacteriocin sensitivity tests. These food samples were analyzed according to method of ISO 11290-1 [28] in a previous study [29] and colonies grown on PALCAM agar were collected and identified. Additionally, L. monocytogenes ATCC 7644, L. monocytogenes RSKK 02028 (Refik Saydam National Public Health Agency, National Type Culture Collection, Ankara, Turkey), L. monocytogenes 1505-Viyana and L. monocytogenes 1483 (Culture Collection of Food Engineering Department, Hacettepe University, Ankara, Turkey) were used as reference strains. Strain Pediococcus acidilactici $13[13,30]$ was used to assess bacteriocin sensitivities to the L. monocytogenes strains.

\subsection{Growth of Bacterial Cultures}

Bacteriocin-producing strain P. acidilactici 13 was propagated in Tryptone Glucose Yeast Extract Broth (TGE; prepared from formulation according to DIFCO Tryptone Glucose Extract Medium) at $37^{\circ} \mathrm{C}$ for 24 hours. Stock cultures were maintained at $-20^{\circ} \mathrm{C}$ in TGE broth containing 15\% (v/v) glycerol. Pathogenic strains, Listeria monocytogenes, were activated in Tryptic Soy Broth (TSB, MERCK, Darmstadt, Germany) at $30^{\circ} \mathrm{C}$ for $24 \mathrm{~h}$.

\subsection{Antibiotic Disc Diffusion Susceptibility Test}

Disk diffusion susceptibility tests were performed according to Clinical and Laboratory Standards Institute standard reference procedure [31]. Three to five well isolated colonies of L. monocytogenes were transferred into $10 \mathrm{ml}$ Tryptic Soy Broth (TSB, Merck), incubated at $37^{\circ} \mathrm{C}$ for 24 hours, diluted 1:10 in $9 \mathrm{ml} \mathrm{0.1 \%}$ peptone water (Merck) to a turbidity equivalent to $0.5 \mathrm{McF}$ arland standard (approximately $10^{8} \mathrm{cfu} / \mathrm{ml}$ ), and inoculated onto the entire surface of a dried Mueller-Hinton Agar (MHA, Merck) plate using a sterile cotton swab. The MHA plates were held at room temperature under a biological hood for 10 minutes to allow evaporation/adsorption of free surface liquid.

Antibiotic discs containing $10 \mu \mathrm{g}$ streptomycin (S10), $30 \mu \mathrm{g}$ vancomycin (VA30), $120 \mu \mathrm{g}$ gentamicin (CN120), $50 \mu \mathrm{g}$ fosfomycin (FOS50), $5 \mu \mathrm{g}$ rifampicin (RD5), 30 $\mu \mathrm{g}$ tetracycline (TE30), 10 Units penicillin G (P10), 15 $\mu \mathrm{g}$ erythromycin (E15), $30 \mu \mathrm{g}$ chloramphenicol (C30), 5 $\mu \mathrm{g}$ trimethoprim (W5) (Oxoid) were placed on the surface of each inoculated MHA plate. After incubation for $24 \mathrm{~h}$ at $37^{\circ} \mathrm{C}$, the diameter (in $\mathrm{mm}$ ) of the zone around each disk was measured and interpreted in accordance with the Clinical and Laboratory Standards Institute Standards guidelines [31], to classify the antibiotic sensitivity of each isolate. Staphylococcus aureus ATCC 6538 was used as standard strain.

\subsection{Well Diffusion Assay}

The antimicrobial activity of bacteriocin-producing $P$. acidilactici 13 was tested against $18 \mathrm{~L}$. monocytogenes strains by well diffusion assay [32]. For this study, $24 \mathrm{~h}$ TGE Broth culture of the bacteriocin-producing isolate was centrifuged at $3214 \times \mathrm{g}$ for 10 minutes. Thereafter, the supernatant fluid was collected and filtered through a $0.45 \mu \mathrm{m}$ pore-size filter (Sartorius, Germany). Wells of 8 $\mathrm{mm}$ diameter were cut on TGE Agar plates, and $50 \mu \mathrm{l}$ portions from the culture supernatant filtrates of the strain were placed into the wells and allowed to diffuse into the agar overnight at $4^{\circ} \mathrm{C}$. Portions $(50 \mu \mathrm{l})$ of $24 \mathrm{~h} L$. monocytogenes cultures were inoculated into $8 \mathrm{ml}$ soft TGE Agar at $45^{\circ} \mathrm{C}$ and poured onto the plates. Zones of 
inhibition were measured after incubation at $30^{\circ} \mathrm{C}$ for 18 $24 \mathrm{~h}$.

\section{Results and Discussion}

Antibiotic sensitivities of fourteen L. monocytogenes strains isolated from foods were tested with disc diffusion assay against ten different antibiotics. Disc diffusion assay results showed that all strains including reference strains were susceptible to penicillin $\mathrm{G}$, vancomycin, tetracycline, chloramphenicol, rifampicin, erythromycin, gentamicin and trimethoprim (Table 1, Figure 1). Although L. monocytogenes isolates are susceptible to a wide range of antibiotics, this pathogen has a natural resistance to nalidixic acid, fosfomycin and the third generation cephalosporins $[33,34]$. Moreover, fosfomycin is included in commercial selective media used for Listeria detection because of the fosfomycin resistance of this pathogen [19]. Even though the percentage is very low, fosfomycin resistance of $L$. monocytogenes from meat and fish samples has been

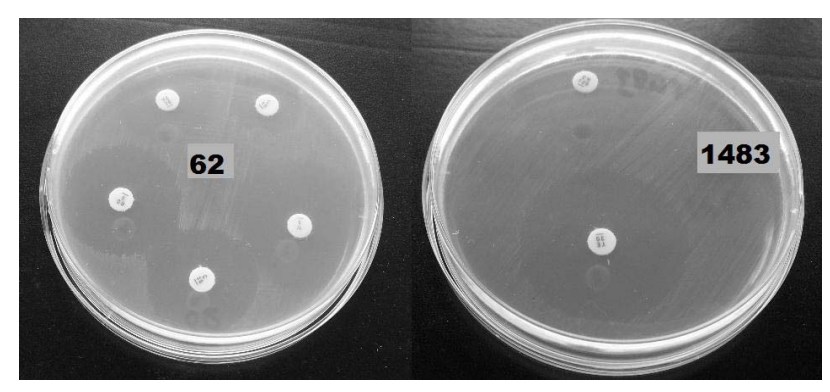

Figure 1. MHA plates showing the effect of the antibiotics to strain Listeria monocytogenes 62 (left) and Listeria monocytogenes 1483 (right).

Table 1. Antibiotic sensitivity of Listeria monocytogenes strains isolated from various foods.

\begin{tabular}{|c|c|c|c|c|}
\hline \multirow{2}{*}{ Antibiotics } & \multirow{2}{*}{ Dose $(\mu \mathrm{g} /$ disc $)$} & \multicolumn{3}{|c|}{ Sensitivity of the isolates (\%) } \\
\hline & & $\mathrm{R}$ & I & $\mathrm{S}$ \\
\hline Penicilin G & $10 \mathrm{IU}$ & 0 & 0 & 100 \\
\hline Vancomycin & 30 & 0 & 0 & 100 \\
\hline Tetracycline & 30 & 0 & 0 & 100 \\
\hline Chloramphenicol & 30 & 0 & 0 & 100 \\
\hline Rifampicin & 5 & 0 & 0 & 100 \\
\hline Erythromycin & 15 & 0 & 0 & 100 \\
\hline Gentamicin & 120 & 0 & 0 & 100 \\
\hline Trimethoprim & 5 & 0 & 0 & 100 \\
\hline Streptomycin & 10 & 7.1 & 0 & 92.9 \\
\hline Fosfomycin & 50 & 92.9 & 0 & 7.1 \\
\hline
\end{tabular}

R: resistant, I: intermediate, S: susceptible. reported [35]. Only one L. monocytogenes strain isolated from turkey döner kebap (7.1\%) displayed sensitivity streptomycin was one of three antibiotics that had comparatively higher frequencies $(12.2 \%)$ than other antibiotics. The resistance percentage of $L$. monocytogenes isolates against streptomycin was determined as $19.30 \%$ by Morobe et al. [24].

Ampicillin, rifampicin or penicillin alone or in combination with gentamicin is standard antibiotic therapy for listeriosis. Also, trimethoprim with sulfamethoxazole is used especially for patients with allergy to penicillin. The other antibiotics used for the treatment of listeriosis are vancomycin, erythromycin, tetracycline and chloramphenicol [7,14]. In our study, L. monocytogenes isolates were highly sensitive to streptomycin $(92.9 \%)$, vancomycin $(100 \%)$, gentamicin $(100 \%)$, rifampicin $(100 \%)$, tetracycline $(100 \%)$, penicillin G (100\%), erythromycin (100\%), chloramphenicol $(100 \%)$ and trimethoprim (100\%) but resistant to fosfomycin $(92.9 \%$; Table 1). In other words, the L. monocytogenes strains tested in the current study were susceptible to the antibiotics used for the treatment of listeriosis.

Another important issue regarding antibiotic resistance of L. monocytogenes is their multiple resistances since they may cause failure of antibiotic therapy of listeriosis [7]. Multiple resistant L. monocytogenes strains have been reported [27,36]. However, multiple resistances among the isolates tested in the present study were not observed.

L. monocytogenes can survive in a wide variety of foodstuffs and its survival times are generally longer at lower temperatures [1]. Application of bacteriocins may help reduce the use of chemical preservatives and/or the intensity of heat and other physical treatments to destroy the pathogens. The resulting minimally processed foods giving home-made appeal to the consumers with least amount of chemical preservatives satisfy the demands of consumers for foods that are fresh tasting, ready to eat, and lightly preserved [37]. Furthermore, pediocin treatment alone or in combination with organic acids showed a stronger effect against survival of $L$. monocytogenes on vegetables [38].

These antimicrobial compounds are mainly used in meat products, but their application to dairy products is being evaluated because of antilisterial activity. These peptides have a wide $\mathrm{pH}$ range for activity and they are not affected by heating or freezing [11]. Studies have been focused on the anti-listerial effect of pediocin-like bacteriocins in foods [14,15,39-41]. However, the increased resistance of Listeria species against class IIa bacteriocins may limit the potential role of these antimicrobial compounds in biopreservation [42]. Moreover, natural resistance to class IIa bacteriocins has been reported in $1 \%$ $8 \%$ of tested wild type strains [43]. We have previously reported [15] resistance of strain 558 of L. monocyto- 
genes, a strain isolated from pork [44], to culture supernatants of $P$. acidilactici 13. However, the results in the present study are not in agreement with the study by Cosansu et al. [15]. In our study, the results of well diffusion assay showed that all strains tested were inhibited by the cell-free supernatant of a bacteriocin-producing strain, Pediococcus acidilactici 13 , with the inhibition zones ranging from 16.00 to $24.50 \mathrm{~mm}$ (Table 2). The largest inhibition zone corresponded to L. monocytogenes strain 44 isolated from sausage, while the narrowest inhibition zone was against strain 48 isolated from raw minced beef.

In this study, we report on the antibiotic resistance pattern and bacteriocin sensitivity of $14 \mathrm{~L}$. monocytogenes strains. According to antibiotic disk diffusion assay results, all $L$. monocytogenes strains were sensitive to the antibiotics commonly used for treatment of listeriosis. Interestingly, some L. monocytogenes strains were resistant to antibiotics: streptomycin and fosfomycin. Regarding sensitivity to the cell free-supernatant of the bacteriocin-producing strain $P$. acidilactici 13, all $L$. monocytogenes strains were found to be inhibited. These results provide useful information on antibiotic resistance of $L$. monocytogenes

Table 2. The inhibition effect of the bacteriocin produced by Pediococcus acidilactici 13 on L. monocytogenes strains*"

\begin{tabular}{|c|c|}
\hline Listeria monocytogenes strains & Inhibition zone diameter $(\mathrm{mm})$ \\
\hline 43 & $22.00 \pm 0.00$ \\
\hline 44 & $24.50 \pm 0.71$ \\
\hline 48 & $16.00 \pm 5.66$ \\
\hline 51 & $19.50 \pm 0.71$ \\
\hline 56 & $19.50 \pm 0.71$ \\
\hline 58 & $19.00 \pm 2.83$ \\
\hline 62 & $19.00 \pm 1.41$ \\
\hline 78 & $22.50 \pm 0.71$ \\
\hline 86 & $21.50 \pm 2.12$ \\
\hline 92 & $23.00 \pm 1.41$ \\
\hline 99 & $19.00 \pm 1.41$ \\
\hline 101 & $21.00 \pm 1.41$ \\
\hline 103 & $22.50 \pm 0.71$ \\
\hline 107 & $17.00 \pm 2.83$ \\
\hline ATCC 7644 & $21.50 \pm 4.95$ \\
\hline 02028 & $21.00 \pm 2.83$ \\
\hline 1505-Viyana & $21.00 \pm 1.41$ \\
\hline 1483 & $19.00 \pm 2.83$ \\
\hline
\end{tabular}

\footnotetext{
"Values are means of $\mathrm{n}=2 \pm \mathrm{SD}$.
}

strains isolated from foods. Further, the findings can potentially be used to develop bacteriocin-based interventions to guard against the hazards associated with L. monocytogenes in ready-to-eat meat and poultry products.

\section{REFERENCES}

[1] M. W. Griffiths, "Listeria: Properties and Occurrence," In: B. Caballero, L. Trugo and P. M. Finglas, Eds., Encyclopedia of Food Science, Food Technology and Nutrition, 2nd Edition, London Academic Press, London, 2003, pp. 3562-3573. doi:10.1016/B0-12-227055-X/00707-0

[2] V. K. Juneja, "Predictive Model for the Combined Effect of Temperature, Sodium Lactate and Sodium Diacetate on the Heat Resistance of Listeria monocytogenes in Beef," Journal of Food Protection, Vol. 66, No. 5, 2003, pp. 804-811.

[3] S. A. Al-Zeyara, B. Jarvis and B. M. Mackey, "The Inhibitory Effect of Natural Microflora of Food on Growth of Listeria monocytogenes in Enrichment Broths," International Journal of Food Microbiology, Vol. 145, No. 1, 2011, pp. 98-105. doi:10.1016/j.ijfoodmicro.2010.11.036

[4] B. Y. Chen, R. Pyla, T. J. Kim, J. L. Silva and Y. S. Jung, "Antibiotic Resistance in Listeria Species Isolated from Catfish Fillets and Processing Environment," Letters in Applied Microbiology, Vol. 50, No. 6, 2010, pp. 626-632. doi:10.1111/j.1472-765X.2010.02843.x

[5] U. T. Şireli and A. Gücükoğlu, "Prevalence and Antibiotic Resistance of Listeria spp. Isolated from Ready-toEat Foods in Ankara," Turkish Journal of Veterinary and Animal Science, Vol. 32, No. 2, 2008, pp. 131-135.

[6] L. O'Connor, M. O'Leary, N. Leonard, M. Godinho, C. O'Reilly, L. Coffey, J. Egan and R. O'Mahony, "The Characterization of Listeria spp. Isolated from Food Products and the Food-Processing Environment," Letters in Applied Microbiology, Vol. 51, No. 5, 2010, pp. 490498. doi:10.1111/j.1472-765X.2010.02928.x

[7] G. Pesavento, B. Ducci, D. Nieri, N. Comodo and A. Lo Nostro, "Prevalence and Antibiotic Susceptibility of Listeria spp. Isolated from Raw Meat and Retail Foods," Food Control, Vol. 21, No. 5, 2010, pp. 708-713. doi:10.1016/i.foodcont.2009.10.012

[8] O. A. Byelashov, H. Daskalov, I. Geornaras, P. A. Kendall, K. E. Belk, J. A. Scanga, G. C. Smith and J. N. Sofos, "Reduction of Listeria monocytogenes on Frankfurters Treated with Lactic Acid Solutions of Various Temperatures," Food Microbiology, Vol. 27, No. 6, 2010, pp. 783-790. doi:10.1016/j.fm.2010.04.003

[9] T. M. Osaili, A. R. Alaboudi and E. A. Nesiar, "Prevalence of Listeria spp. and Antibiotic Susceptibility of Listeria monocytogenes Isolated from Raw Chicken and Ready-to-Eat Chicken Products in Jordan," Food Control, Vol. 22, No. 3-4, 2011, pp. 586-590. doi:10.1016/j.foodcont.2010.10.008

[10] J. N. Sofos and I. Geornaras, "Overview of Current Meat Hygiene and Safety Risks and Summary of Recent Studies on Biofilms, and Control of Escherichia coli O157:H7 in Nonintact, and Listeria monocytogenes in Ready-to-Eat, 
Meat Products," Meat Science, Vol. 86, No. 1, 2010, pp. 2-14. doi:10.1016/j.meatsci.2010.04.015

[11] A. Sobrino-Lopez and O. Martin-Belloso, "Use of Nisin and Other Bacteriocins for Preservation of Dairy Products," International Dairy Journal, Vol. 18, No. 4, 2008, pp. 329-343. doi:10.1016/j.idairyj.2007.11.009

[12] L. H. Deegan, P. D. Cotter, C. Hill and P. Ross, "Bacteriocins: Biological Tools for Bio-Preservation and Shelflife Extension," International Dairy Journal, Vol. 16, 2006, pp. 1058-1071. doi:10.1016/j.idairyj.2005.10.026

[13] E. G. Altuntas, S. Cosansu and K. Ayhan, "Some Growth Parameters and Antimicrobial Activity of a Bacteriocin Producing Strain Pediococcus sp 13," International Journal of Food Microbiology, Vol. 141, No. 1, 2010, pp. 28-31. doi:10.1016/j.ijfoodmicro.2010.04.024

[14] A. H. Çon, H. Y. Gökalp and M. Kaya, "Antagonistic Effect on Listeria monocytogenes and L. innocua of a Bacteriocin-Like Metabolite Produced by Lactic Acid Bacteria Isolated from Sucuk," Meat Science, Vol. 59, No. 4, 2001, pp. 437-441. doi:10.1016/S0309-1740(01)00099-7

[15] S. Cosansu, I. Geornaras, K. Ayhan and J. N. Sofos, "Control of Listeria monocytogenes by a Bacteriocin-Like Metabolite Producing Pediococcus Strain in a Dry Fermented Sausage 'Sucuk' and on a Non-Fermented Product 'Turkey Breast'," Journal of Food and Nutrition Research, Vol. 49, No. 4, 2010, pp. 206-214.

[16] M. Zhu, M. Du, J. Cordray and D. U. Ahn, "Control of Listeria monocytogenes Contamination in Ready-to-Eat Meat Products," Comprehensive Reviews in Food Science and Food Safety, Vol. 4, 2005, pp. 34-42. doi:10.1111/j.1541-4337.2005.tb00071.x

[17] E. Charpentieer and P. Courvalin, "Antibiotic Resistance in Listeria spp.," Antimicrobial Agents and Chemotherapy, Vol. 43, No. 9, 1999, pp. 2103-2108.

[18] S. P. Oliver, S. E. Murinda and B. M. Jayarao, "Impact of Antibiotic Use in Adult Dairy Cows on Antimicrobial Resistance of Veterinary and Human Pathogens: A Comprehensive Review," Foodborne Pathogens and Disease, Vol. 8, No. 3, 2011, pp. 337-355. doi:10.1089/fpd.2010.0730

[19] P. Aureli, A. M. Ferini, V. Mannoni, S. Hodzic, C. Wedell-Weergaarda and B. Olivab, "Susceptibility of Listeria monocytogenes Isolated from Food in Italy to Antibiotics," International Journal of Food Microbiology, Vol. 83, No. 3, 2003, pp. 325-330. doi:10.1016/S0168-1605(02)00381-1

[20] S. Bertrand, G. Huys, M. Yde, K. D’Haene, F. Trdy, M. Vrints, J. Swings and J. M. Collard, "Detection and Characterization of tet(M) in Tetracycline-Resistant Listeria Strains from Human and Food-Processing Origins in Belgium and France," Journal of Medical Microbiology, Vol. 54, No. 12, 2005, pp. 1151-1156. doi:10.1099/jmm.0.46142-0

[21] D. Walsh, G. Duffy, J. J. Sheridan, I. S. Blair and D. A. McDowell, "Antibiotic Resistance among Listeria, including Listeria monocytogenes, in Retail Foods," Journal of Applied Microbiology, Vol. 90, No. 4, 2001, pp. 517-522. doi:10.1046/j.1365-2672.2001.01273.x
[22] M. Conter, D. Paludi, V. D’Orio, A. Vergara and A. Ianieri, "Antimicrobial Susceptibility of Listeria monocytogenes Isolated from Food and Food-Processing Environment," Annali Della Facolta di Medicina Veterina del Studi di Parma, Vol. 27, 2007, pp. 157-164.

[23] H. Ennaji, M. Timinouni, M. M. Ennaji, M. Hassar and N. Cohen, "Characterization and Antibiotic Susceptibility of Listeria monocytogenes Isolated from Poultry and Red Meat in Morocco," Journal of Infection and Drug Resistance, Vol. 1, No. 1, 2008, pp. 45-50.

[24] I. C. Morobe, C. L. Obi, M. A. Nyila, B. A. Gashe and M. I. Matsheka, "Prevalence, Antimicrobial Resistance Profiles of Listeria monocytogenes from Various Foods in Gaborone, Botswana," African Journal of Biotechnology, Vol. 8, No. 22, 2009, pp. 6383-6387.

[25] N. Yücel, S. Çıtak and M. Önder, "Prevalence and Antibiotic Resistance of Listeria Species in Meat Products in Ankara, Turkey," Food Microbiology, Vol. 22, 2005, pp. 241-245. doi:10.1016/j.fm.2004.03.007

[26] D. Palumbo, M. Iannaccone, A. Porta and R. Capparelli, "Experimental Antibacterial Therapy with Puroindolines, Lactoferrin and Lysozyme in Listeria monocytogenesInfected Mice," Microbes and Infection, Vol. 12, No. 7, 2010, pp. 538-545.

doi:10.1016/j.micinf.2010.03.010

[27] H. Yan, S. B. Neogi, Z. Mo, W. Guan, Z. Shen, S. Zhang, L. Li, S. Yamasaki, L. Shi and N. Zhong, "Prevalence and Characterization of Antimicrobial Resistance of Foodborne Listeria monocytogenes Isolates in Hebei Province of Northern China, 2005-2007," International Journal of Food Microbiology, Vol. 144, No. 2, 2010, pp. 310-316. doi:10.1016/j.ijfoodmicro.2010.10.015

[28] ISO 11290-1, "Microbiology of Food and Animal Feeding Stuffs-Horizontal Method for the Detection and Enumeration of Listeria monocytogenes, Part 1: Detection Method/Amendment 1: Modification of the Isolation Media and the Haemolysis Test, and Inclusion of Precision Data. Brussels: European Committee for Standardization (EN ISO 11290-1:1996/Am1:2004)," 2004.

[29] D. Koçan, "Minimum Inhibition Concentration for Determining of Listeria monocytogenes," $\mathrm{PhD}$ Dissertation, Ankara University Graduate School of Natural and Applied Sciences, Ankara, Turkey, 2007.

[30] S. Cosansu, H. Kuleasan, K. Ayhan and L. Materon, "Antimicrobial Activity and Protein Profiles of Pediococcus spp. Isolated from Turkish Sucuk," Journal of Food Processing and Preservation, Vol. 31, No. 2, 2007, pp. 190-200. doi:10.1111/j.1745-4549.2007.00122.x

[31] M. A. Wikler, "Performance Standards for Antimicrobial Susceptibility Testing, Sixteenth Informational Supplement, M100-S16," Clinical and Laboratory Standards Institute (CLSI), Vol. 26, No. 3, 2006, Pennsylvania.

[32] U. Schillinger and F. K. Lücke, "Identification of Lactobacilli from Meat and Meat Products," Food Microbiology, Vol. 4, No. 3, 1987, pp. 199-208. doi:10.1016/0740-0020(87)90002-5

[33] H. Hof, "Therapeutic Options," FEMS Immunology and Medical Microbiology, Vol. 35, No. 3, 2003, pp. 203-205. doi:10.1016/S0928-8244(02)00466-2 
[34] R. Troxler, A. Von Graevenitz, G. Funke, B. Wiedemann and I. Stock, "Natural Antibiotic Susceptibility of Listeria Species: L. grayi, L. innocua, L. ivanovii, L. monocytogenes, L. seeligeri and L. welshimeri Strains," Clinical Microbiology and Infection, Vol. 6, No. 10, 2000, pp. 525-535. doi:10.1046/j.1469-0691.2000.00168.x

[35] M. Conter, D. Paludi, E. Zanardi, S. Ghidini, A. Vergara and A. Ianieri, "Characterization of Antimicrobial Resistance of Foodborne Listeria monocytogenes," International Journal of Food Microbiology, Vol. 128, No. 3, 2009, pp. 497-500. doi:10.1016/j.ijfoodmicro.2008.10.018

[36] O. R. Rodas-Suárez, J. F. Flores-Pedroche, J. M. Betancourt-Rule, E. I. Quiñones-Ramírez and C. VázquezSalinas, "Occurrence and Antibiotic Sensitivity of Listeria monocytogenes Strains Isolated from Oysters, Fish, and Estuarine Water," Applied and Environmental Microbiology, Vol. 72, No. 11, 2006, pp. 7410-7412. doi:10.1128/AEM.00956-06

[37] A. Galvez, R. L. Lopez and H. Abriouel, "Application of Bacteriocins in the Control of Foodborne Pathogenic and Spoilage Bacteria," Critical Reviews in Biotechnology, Vol. 28, No. 2, 2008, pp. 125-152. doi: $10.1080 / 07388550802107202$

[38] L. Settani and A. Corsetti, "Application of Bacteriocins in Vegetable Food Biopreservation," International Journal of Food Microbiology, Vol. 121, No. 2, 2008, pp. 123138. doi:10.1016/j.ijfoodmicro.2007.09.001

[39] D. Bizani, J. A. C. Morrissy, A. P. M. Dominguez and A. Brandelli, "Inhibition of Listeria monocytogenes in Dairy Products Using the Bacteriocin-Like Peptide Cerein 8A," International Journal of Food Microbiology, Vol. 121,
No. 2, 2008, pp. 229-233.

doi:10.1016/j.ijfoodmicro.2007.11.016

[40] J. W. Nielsen, J. S. Dickson and J. D. Crouse, "Use of a Bacteriocin Produced by Pediococcus acidilactici to Inhibit Listeria monocytogenes Associated with Fresh Meat," Applied and Environmental Microbiology, Vol. 56, 1990, pp. 2142-2145.

[41] J. C. Nieto-Lozano, J. I. Reguera-Useros, M. C. PelaezMartinez and A. H. de la Torre, "Effect of a Bacteriocin Produced by Pediococcus acidilactici against Listeria monocytogenes and Clostridium perfringens on Spanish Raw Meat," Meat Science, Vol. 72, 2006, pp. 57-61. doi:10.1016/j.meatsci.2005.06.004

[42] V. Vadyvaloo, S. Arous, A. Gravesen, Y. Héchard, R. Chauhan-Haubrock, J. W. Hastings and M. Rautenbach, "Cell-Surface Alterations in Class IIa Bacteriocin-Resistant Listeria monocytogenes Strains," Microbiology, Vol. 150, No. 9, 2004, pp. 3025-3033. doi:10.1099/mic.0.27059-0

[43] A. Gravesen, M. Ramnath, K. B. Rechinger, N. Andersen, L. Jänsch, Y. Héchard, J. W. Hastings and S. Knøchel, "High-Level Resistance to Class IIa Bacteriocins Is Associated with One General Mechanism in Listeria monocytogenes," Microbiology, Vol. 148, No. 8, 2002, pp. 2361-2369.

[44] I. M. Barmpalia-Davis, I. Geornaras, P. A. Kendall and J. N. Sofos, "Differences in Survival among 13 Listeria monocytogenes Strains in a Dynamic Model of the Stomach and Small Intestine," Applied Environmental Microbiology, Vol. 74, No. 17, 2008, pp. 5563-5567.

doi:10.1128/AEM.00319-08 